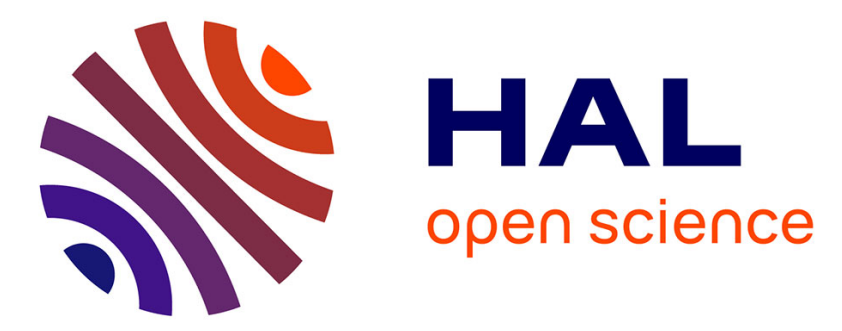

\title{
Moulting patterns drive within-individual variations of stable isotopes and mercury in seabird body feathers: implications for monitoring of the marine environment
}

Alice Carravieri, Paco Bustamante, Carine Churlaud, Aymeric Fromant, Yves Cherel

\section{To cite this version:}

Alice Carravieri, Paco Bustamante, Carine Churlaud, Aymeric Fromant, Yves Cherel. Moulting patterns drive within-individual variations of stable isotopes and mercury in seabird body feathers: implications for monitoring of the marine environment. Marine Biology, 2014, 161 (4), pp.963-968. 10.1007/s00227-014-2394-x . hal-00978917

\section{HAL Id: hal-00978917 https://hal.science/hal-00978917}

Submitted on 14 Apr 2014

HAL is a multi-disciplinary open access archive for the deposit and dissemination of scientific research documents, whether they are published or not. The documents may come from teaching and research institutions in France or abroad, or from public or private research centers.
L'archive ouverte pluridisciplinaire HAL, est destinée au dépôt et à la diffusion de documents scientifiques de niveau recherche, publiés ou non, émanant des établissements d'enseignement et de recherche français ou étrangers, des laboratoires publics ou privés. 
Moulting patterns drive within-individual variations of stable isotopes and mercury in seabird body feathers: implications for monitoring of the marine environment

Alice Carravieri $\cdot$ Paco Bustamante $\cdot$ Carine Churlaud $\cdot$ Aymeric Fromant $\cdot$ Yves Cherel

A. Carravieri (corresponding author) $\cdot$ A. Fromant $\cdot$ Y. Cherel

Centre d'Etudes Biologiques de Chizé, UPR 1934 du Centre National de la Recherche Scientifique, BP 14, 79360 Villiers-en-Bois, France

e-mail: alice.carravieri@cebc.cnrs.fr
A..Carravieri $\cdot$ P. Bustamante $\cdot$ C. Churlaud $\cdot$ A. Fromant

Littoral Environnement et Sociétés (LIENSs), UMRi 7266 CNRS-Université de la Rochelle, 2 rue Olympe de Gouges, 17000 La Rochelle, France 
Abstract. One major limitation in the use of body feathers of seabirds as a monitoring tool of the trophic structure and contamination levels of marine ecosystems is the degree of heterogeneity in feather chemical composition within individuals. Here, we tested the hypothesis that moulting patterns drive body feather heterogeneity, with synchronous moult minimizing within-individual variations, in contrast to asynchronous feather growth. Chicks of white-chinned petrels Procellaria aequinoctialis (representative of bird chicks) and adults of king penguins Aptenodytes patagonicus (representative of adult penguins) that moult their body feathers synchronously showed very low within-individual variations in their feather $\delta^{13} \mathrm{C}$ and $\delta^{15} \mathrm{~N}$ values and $\mathrm{Hg}$ concentrations. By contrast, body feathers of adults of Antarctic prions Pachyptila desolata (representative of adult seabirds with asynchronous feather growth during a protracted moult) presented much higher within-individual variances for the three parameters. These findings have three important implications for birds presenting a synchronous body moult. (i) They suggest that all body feathers from the same individual have identical $\delta^{13} \mathrm{C}$ and $\delta^{15} \mathrm{~N}$ values and $\mathrm{Hg}$ content. (ii) They predict negligible withinindividual variations in the body feather values of other useful stable isotopes, such as $\delta^{2} \mathrm{H}$ and $\delta^{34} \mathrm{~S}$, as well as in the concentrations of other compounds that are deposited in the keratin structure. (iii) Analysis of one or any number of pooled body feathers is equally representative of the individual. In conclusion, we recommend that long-term routine monitoring investigations focus on birds presenting synchronous rather than asynchronous moult of body feathers both in marine and terrestrial environments. This means targeting chicks rather than adults and, for seabirds, penguins rather than adults of flying species.

Keywords: biomonitoring $\cdot$ birds $\cdot$ moult $\cdot$ Southern Ocean $\cdot$ trophic ecology 


\section{Introduction}

Feathers are used extensively in avian biology, chemoecology and toxicology because they can be easily collected and are metabolically inert after synthesis, thus preserving their chemical composition almost indefinitely. For instance, stable isotope analyses of feathers have provided insights into many aspects of avian ecology (Inger and Bearhop 2008; Hobson 2011) and feathers are considered as excellent non-destructive tools for monitoring contaminants, including heavy metals and persistent organic pollutants (Burger 1993; GarcíaFernández et al. 2013). More recently, the application of the stable isotope method to ecotoxicological studies has granted insight into patterns of contamination among sites, species and individuals (e.g. Ofukany et al. 2012; Ramos et al. 2013). Feathers from museum collections have been further used to depict historical changes in birds' foraging ecology and contaminant exposure (Vo et al. 2011; Jaeger and Cherel 2011).

Ideally, a monitoring tool must show little within- and between-individual variations in the levels of targeted compounds in order to facilitate the statistical description of spatiotemporal trends within a population. Indeed, a main limitation in the use of feathers is withinindividual heterogeneity both between and within feather types. For example, changes in foraging habitat or diet during moult lead to large variations in feather $\delta^{13} \mathrm{C}$ and $\delta^{15} \mathrm{~N}$ values, respectively (Jaeger et al. 2010), and feathers that grow at different times present different mercury $(\mathrm{Hg}$ ) concentrations, as the $\mathrm{Hg}$ body pool is progressively depleted during the moult (Furness et al. 1986; Braune and Gaskin 1987). For both scientific and ethical reasons, body feathers are generally considered as the best feather type to sample (Furness et al. 1986; Jaeger et al. 2009), but few investigations looked at their stable isotope values and contaminant levels of within-individual heterogeneity (Thompson et al. 1993; Bond and Diamond 2008; Jaeger et al. 2009, 2010; Brasso et al. 2013). Since body feathers grow asynchronously during the whole moulting period, a main recurrent problem is that the 
precise timing of synthesis of a given body feather remains unknown. However, the temporal drawback can be eluded in the case of synchronous or almost synchronous moult of body feathers. Indeed, assuming a constant growth rate for all body feathers, a synchronous growth theoretically means that all body feathers should have the same chemical composition and thus should show identical stable isotope values and contaminant levels.

Here, we tested this hypothesis by measuring $\delta^{13} \mathrm{C}$ and $\delta^{15} \mathrm{~N}$ values and $\mathrm{Hg}$ concentrations in four body feathers from the same individuals of three groups of marine birds showing different moulting patterns. Seabirds are useful organisms to biomonitor marine ecosystems, because they are long-lived animals that prey at the top of the marine food webs (Furness and Camphuysen 1997; Burger and Gochfeld 2004). Selected models were:

1. Chicks of white-chinned petrels Procellaria aequinoctialis. Chicks of this species were selected as representative of bird chicks, which present a complete moult with body feathers growing almost synchronously towards the end of the chick-rearing period. Whitechinned petrel chicks have the advantage of showing significant between-individual variations in their feather stable isotope values (Jaeger et al. 2010), being thus a potentially good model to compare feather heterogeneity between and within individuals.

2. Adults of Antarctic prions Pachyptila desolata. Adults of this species were selected as representative of adults of flying seabirds that disperse after breeding and moult far away from their breeding grounds during the inter-nesting period. Moult is sequential and generally protracted over several weeks to months (Bridge 2006). Antarctic prions breed within the Southern Ocean and their feather $\delta^{13} \mathrm{C}$ values indicate moulting primarily in northern warmer waters (Cherel et al. 2006).

3. Adults of king penguins Aptenodytes patagonicus. Adults of this species were selected as representative of penguins, which present a unique moulting pattern among birds. Penguins renew their whole plumage while fasting ashore, because transient reduction in thermal insulation during moult prevents them from going at sea. Consequently, all their body 
feathers grow simultaneously at the expense of energy reserves that are built up during the pre-moulting foraging period of hyperphagia at sea (Groscolas and Cherel 1992; Cherel et al. 1994).

As body feathers grow simultaneously in white-chinned petrel chicks and king penguin adults, but not in Antarctic prion adults, our driving hypothesis was that feather $\delta^{13} \mathrm{C}$ and $\delta^{15} \mathrm{~N}$ values and $\mathrm{Hg}$ concentrations would present lower within- than between-individual variations in the two former groups and would show an opposite pattern in the latter species. The main consequence of these moulting strategies is that chicks and penguins should be more suitable avian models than adults of flying species for long-term monitoring of the marine environment.

\section{Materials and methods}

Body feathers from white-chinned petrel chicks and king penguin adults were collected on Possession Island (46 30' S, 51 ${ }^{\circ} 45^{\prime}$ E), Crozet Archipelago in 2007 and 2005, respectively. King penguin adults were sampled during their annual moult, while well-feathered whitechinned petrel chicks were sampled at the end of the chick-rearing period. AP adults were collected on the Kerguelen Islands (49 $21^{\prime}$ S, $\left.70^{\circ} 18^{\prime} \mathrm{E}\right)$ during the 2011-2012 austral summer. Birds were found dead or dying after being trapped in the vegetation (Acaena adscendens); they were stored at $-20^{\circ} \mathrm{C}$ until dissection at the Centre d'Etudes Biologiques de Chizé, France. For all species, several whole body feathers per individual were pulled out from the lower back (dorsal tract) and stored dry in sealed plastic bags until analysis at the University of La Rochelle, France. Prior to chemical analysis, whole feathers were cleaned as described in Blévin et al. (2013) and then oven dried for $48 \mathrm{hr}$ at $50^{\circ} \mathrm{C}$. Every whole feather was homogenized by cutting it with scissors into small fragments and a subsample of $\sim 0.3 \mathrm{mg}$ was packed into tin containers for stable isotope analysis. The relative abundance of carbon and 
nitrogen isotopes were determined with a continuous flow mass spectrometer (Thermo Scientific Delta V Advantage) coupled to an elemental analyser (Thermo Scientific Flash EA 1112). Results are presented in the usual $\delta$ notation relative to Vienna PeeDee Belemnite and atmospheric $\mathrm{N}_{2}$ for $\delta^{13} \mathrm{C}$ and $\delta^{15} \mathrm{~N}$, respectively. Replicate measurements of internal laboratory standards (acetanilide) indicated measurement errors $<0.15 \%$ for both $\delta^{13} \mathrm{C}$ and $\delta^{15} \mathrm{~N}$ values. The remaining homogenized subsample of every feather was then analysed for total $\mathrm{Hg}$ in an Advanced Mercury Analyzer spectrophotometer (Altec AMA 254) following Blévin et al. (2013). Whenever possible, $\mathrm{Hg}$ analysis was repeated twice and the relative standard deviation between runs calculated $(<10 \%$ for all samples). Accuracy was checked using a certified reference material (Tort-2 Lobster Hepatopancreas, NRC, Canada; certified Hg concentration: $0.27 \pm 0.06 \mu \mathrm{g} \mathrm{g}^{-1}$ dry weight). Our measured values were $0.268 \pm 0.022 \mu \mathrm{g} \mathrm{g}^{-1}$ dry weight $(n=14)$. Blanks were analysed at the beginning of each set of samples and the detection limit of the method was $0.005 \mu \mathrm{g} \mathrm{g}^{-1}$ dry weight. Data of $\mathrm{Hg}$ concentrations are presented relative to the dry weight $(\mathrm{dw})$.

Statistical analyses were performed using R 2.15. (R Core Team 2012). Linear mixed effect models were used in order to test the repeatability of feather stable isotope values and Hg concentrations within individuals. Random effect models with the individual as a random intercept were constructed for the three groups of birds. The variance explained by the model $(d)$, i.e. the between-individual variance, and the residual variance $(\sigma)$ were used to calculate the intra-class correlation coefficient (ICC) as $d^{2} /\left(d^{2}+\sigma^{2}\right)$, which is a measure of repeatability (Nakagawa and Schielzeth 2010). ICC ranges from 0 to 1, with values close to 1 meaning that most of the variance is explained by between-individual differences. Stable isotope values and Hg concentrations are means \pm standard deviation (SD). 


\section{Results}

Feather stable isotope values and $\mathrm{Hg}$ concentrations were measured in four different body feathers from 10 white-chinned petrel chicks, 10 Antarctic prion adults and 7 king penguin adults (Table 1; Fig 1). Individual SD were very low and ICC very high for feather $\delta^{13} \mathrm{C}$ and $\delta^{15} \mathrm{~N}$ values and $\mathrm{Hg}$ concentrations of white-chinned petrel chicks and king penguin adults (Tables 1 and 2). By contrast, Antarctic prion adults showed large within-individual variations, i.e. high SD and low ICC in feather $\delta^{13} \mathrm{C}$ and $\delta^{15} \mathrm{~N}$ values and $\mathrm{Hg}$ concentrations. In Antarctic prion adults, individual ranges of stable isotopes values were as large as $4.9 \%$ and $5.6 \%$ in feather $\delta^{13} \mathrm{C}$ and $\delta^{15} \mathrm{~N}$ values, respectively. Noticeably, while feather $\mathrm{Hg}$ concentrations were within the same order of magnitude for the three groups of birds (overall individual range: 1.1 to $3.9 \mu \mathrm{g} \mathrm{g}^{-1} \mathrm{dw}$ ), $\mathrm{CV}$ were much lower in individual white-chinned petrel chicks (3 to 9\%) and king penguin adults ( $<1$ to $8 \%)$ than in Antarctic prion adults (15 to $60 \%)$.

\section{Discussion}

To the best of our knowledge, this study is the first to compare the levels of heterogeneity in stable isotope values and contaminant concentrations of body feathers both within and between individuals in relation to different moulting patterns. The results verified the initial hypothesis stating that a synchronous moult leads to lower within- than between-individual variations in feather $\delta^{13} \mathrm{C}$ and $\delta^{15} \mathrm{~N}$ values and $\mathrm{Hg}$ concentrations, while asynchronous feather growth induces higher levels of feather heterogeneity within individual birds. Adult moult is potentially of variable duration according to sex, age, breeding status, species, phylogeny and environmental constraints. Hence, the synchronous/protracted moult hypothesis merits further investigations focusing on slow-moulting birds (e.g. albatrosses, Bridge 2006), species 
undergoing two moults per year (e.g. terns, Burger et al. 1992), and species with complex moulting patterns (e.g. alcids, Bridge 2004).

Feather $\delta^{13} \mathrm{C}$ and $\delta^{15} \mathrm{~N}$ values and $\mathrm{Hg}$ concentrations showed low variances and high ICC, thus indicating low levels of within-individual variations in white-chinned petrel chicks and king penguin adults. Noticeably, SD of $\delta^{13} \mathrm{C}$ and $\delta^{15} \mathrm{~N}$ values were close to the accuracy of the isotopic method. These findings have three important implications.

1. They suggest that all body feathers that grow simultaneously have the same $\delta^{13} \mathrm{C}$ and $\delta^{15} \mathrm{~N}$ values and $\mathrm{Hg}$ concentrations.

2. When considering the overall feather chemical composition, they predict negligible within-individual variations in other useful stable isotope values of keratin, like $\delta^{2} \mathrm{H}$ and $\delta^{34} \mathrm{~S}$ (Hobson 2011; Ramos et al. 2013) and in the concentrations of other compounds that are deposited in the keratin structure, like trace metals and metalloids, persistent organic pollutants and hormones (Burger 1993; Bortolotti et al. 2009; García-Fernández et al. 2013). This prediction is not verified for at least one group of molecules, the pigments, which can vary qualitatively and quantitatively from one body feather to the other (Stettenheim 2000). It also merits further investigations for those compounds that show a time-dependent deposition in feathers, like steroid hormones (Bortolotti 2010).

3. Analysis of one to several pooled body feathers will provide identical stable isotope values and concentrations in various chemical compounds, meaning that any quantity of body feathers that grow simultaneously is equally representative of the individual. This is particularly relevant for studies including several elements and molecules, because some measurements necessitate only a single body feather (e.g. $\mathrm{Hg}, \delta^{13} \mathrm{C}$ and $\delta^{15} \mathrm{~N}$ ), but others require much more material, and hence several feathers (e.g. organic pollutants; GarcíaFernández et al. 2013).

In contrast to white-chinned petrel chicks and king penguin adults, the amount of variability in feather $\delta^{13} \mathrm{C}$ and $\delta^{15} \mathrm{~N}$ values and $\mathrm{Hg}$ concentrations within individuals was high 
in AP adults. Such high levels of heterogeneity were previously found in the feather isotopic values of adults of light-mantled (Phoebetria palpebrata) and wandering (Diomedea exulans) albatrosses (Jaeger et al. 2009, 2010), and in body feather $\mathrm{Hg}$ concentrations of adults of Arctic (Sterna paradisaea) and common terns (S. hirundo), and of Leach's storm petrels (Oceanodroma leucorhoa) (Bond and Diamond 2008). The within-individual variation of adult flying birds likely results from body feathers being synthesized and replaced at different times during the moulting period (e.g. Battam et al. 2010). This heterogeneity reflects the birds' movements within different water masses and associated dietary shifts (Jaeger et al. 2010), together with changes in body burdens of $\mathrm{Hg}$ (Furness et al. 1986; Braune and Gaskin 1987) during the protracted moult. A positive aspect of feather variability is that measuring the isotopic values of several body feathers per individual can provide valuable information on the foraging strategies of adult birds during the moulting period (Jaeger et al. 2009, 2010). A negative aspect is that it complicates the use of body feathers as an effective monitoring tool because increasing variability can blur temporal and spatial trends. Hence, in a first step, within-individual heterogeneity must be accurately quantified, as well as the minimum number of body feathers to sample, as described for example by Jaeger et al. (2009) and Brasso et al. (2013). In a second step, body feathers of a given individual can be pooled in order to perform a unique measurement per bird. However, uncertainties in the biological interpretation of the data will remain, since, in most cases, practical reasons preclude determining the precise timing of synthesis of the sampled body feathers in relation to the food and feeding ecology of the individuals. Minimizing heterogeneity related to analytical procedure also requires thorough feather homogenisation.

We therefore recommend that long-term routine monitoring investigations on the trophic structure and contamination levels of ecosystems focus on birds presenting synchronous rather than asynchronous moult of body feathers. This means targeting chicks rather than adults (Blévin et al. 2013; this study), and, in the Southern Hemisphere, adult 
penguins rather than adult flying seabirds (Carravieri et al. 2013; this study). Chicks may represent the disadvantage of presenting low magnitude variation in feather $\delta^{15} \mathrm{~N}$ (not $\delta^{13} \mathrm{C}$ ) in relation to varying chick growth rates $(\sim 0.6 \%$, Sears et al. 2009$)$, and museum specimens include only a few well-feathered chicks, thus precluding determining historical changes. Nevertheless, chicks present several advantages over other age-classes.

1. Most seabird chicks can be easily handled since they remain on land, while being fed exclusively by their parents. In addition, chick feathers can be sampled before fledging with minimum disturbance (for example during the annual ringing session in a long-term study colony).

2. The food of chicks and the foraging ecology of parent seabirds can be investigated by collecting stomach samples and using bio-logging. Hence, feather stable isotope values and contaminant levels can be related to the feeding ecology of the animals. Since adult seabirds are central place foragers when breeding, stable isotopes and contaminants in chick feathers likely represent primarily the local environment.

3. Chick moult is easy to study and the time window integrated by chick feathers is well-defined, because growth of body feathers takes place on land in the mid to the second half of the chick-rearing period (Bost 1991; Phillips and Hamer 2000).

4. Working on chicks minimizes the temporal mismatch resulting from different integration times between feather stable isotopes and some contaminants, like $\mathrm{Hg}$ (Bond 2010). Feather $\delta^{13} \mathrm{C}$ and $\delta^{15} \mathrm{~N}$ values reflect the feeding ecology of the birds at the time of feather synthesis (Hobson and Clark 1992; Bearhop et al. 2002), while feathers integrate Hg accumulated in internal tissues during two successive moults (Furness et al. 1986). In chicks, this means the second part of the chick-rearing period (see above) versus a slightly longer period corresponding to the end of down growth (initial chick moult) to the beginning of body feather growth (Stewart et al. 1997), respectively. 
In agreement with Stewart et al. (1997) and Burger and Gochfeld (2004), the present work provides new evidence showing that chick feathers are a useful avian tool for routine biomonitoring of the trophic structure and contaminant bioavailability in the marine environment. By targeting species with different breeding locations and chick-rearing periods (for example summer versus winter breeders), different, but well-defined spatio-temporal scales of the marine environment can be investigated. The present work focuses on seabirds, but it can be generalized to water birds and terrestrial species, since a synchronous or almost synchronous moult of body feathers in chicks before fledging is a general pattern amongst avian species.

Acknowledgements The authors thank fieldworkers who helped with collecting bird feathers,

A. Jaeger for the preparation of some samples, G. Guillou for running stable isotope analysis, and S. Patrick for helpful advice in statistical analyses. The present work was supported financially and logistically by the Région Poitou-Charentes through a $\mathrm{PhD}$ grant to $\mathrm{AC}$, and by the Agence Nationale de la Recherche (program POLARTOP, O. Chastel), the Institut Polaire Français Paul Emile Victor (IPEV, program no. 109, H. Weimerskirch) and the Terres Australes et Antarctiques Françaises (TAAF).

\section{References}

Battam H, Richardson M, Watson AWT, Buttemer WA (2010) Chemical composition and tissue energy density of the cuttlefish (Sepia apama) and its assimilation efficiency by Diomedea albatrosses. J Comp Physiol B 180:1247-1255

Bearhop S, Waldron S, Votier SC, Furness RW (2002) Factors that influence assimilation rates and fractionation of nitrogen and carbon stable isotopes in avian blood and feathers. Physiol Biochem Zool 75:451-458

Blévin P, Carravieri A, Jaeger A, et al. (2013) Wide range of mercury contamination in chicks of Southern Ocean seabirds. PLoS ONE 8:e54508 
Bond AL (2010) Relationships between stable isotopes and metal contaminants in feathers are spurious and biologically uninformative. Environ Pollut 158:1182-1184

Bond AL, Diamond AW (2008) High within-individual variation in total mercury concentration in seabird feathers. Environm Toxicol Chem 27:2375-2377

Bortolotti GR (2010) Flaws and pitfalls in the chemical analysis of feathers: bad news-good news for avian chemoecology and toxicology. Ecol Appl 20:1766-1774

Bortolotti GR, Marchant T, Blas J, Cabezas S (2009) Tracking stress: localisation, deposition and stability of corticosterone in feathers. J Exp Biol 212:1477-1482

Bost CA, Jouventin P (1991) The breeding biology of the gentoo penguin Pygoscelis papua on the Crozet Islands. Ibis 133:14-25

Brasso RL, Drummond BE, Borrett SR, Chiaradia A, Polito MJ, Rey AR (2013) Unique pattern of molt leads to low intra-individual variation in feather mercury concentrations in penguins. Environm Toxicol Chem 32:2331-2334

Braune BM, Gaskin DE (1987) Mercury levels in Bonaparte's gulls (Larus philadelphia) during autumn molt in the Quoddy Region, New Brunswick, Canada. Arch Environ Contam Toxicol 16:539-549

Bridge ES (2004) The effects of intense wing molt on diving in alcids and potential influences on the evolution of molt patterns. J Exp Biol 207:3003-3014

Bridge ES (2006) Influences of morphology and behavior on wing-molt strategies in seabirds. Mar Ornithol $34: 7-19$

Burger J (1993) Metals in avian feathers: bioindicators of environmental pollution. Rev Environ Toxicol 5:203311

Burger J, Gochfeld M (2004) Marine birds as sentinels of environmental pollution. EcoHealth 1:263-274

Burger J, Nisbet IC, Gochfeld M (1992) Metal levels in regrown feathers: Assessment of contamination on the wintering and breeding grounds in the same individuals. J Toxicol Environ Health A 37:363-374

Carravieri A, Bustamante P, Churlaud C, Cherel Y (2013) Penguins as bioindicators of mercury contamination in the Southern Ocean: birds from the Kerguelen Islands as a case study. Sci Total Environ 454455:141-148

Cherel Y, Charrassin JB, Challet E (1994) Energy and protein requirements for molt in the king penguin Aptenodytes patagonicus. Am J Physiol 266 (Regulatory Integrative Comp Physiol 35): R1182-R1188

Cherel Y, Phillips RA, Hobson KA, McGill R (2006) Stable isotope evidence of diverse species-specific and individual wintering strategies in seabirds. Biol Lett 2:301-303 
Furness RW, Camphuysen KCJ (1997) Seabirds as monitors of the marine environment. ICES J Mar Sci 54:726-737

Furness RW, Muirhead SJ, Woodburn M (1986) Using bird feathers to measure mercury in the environment: relationships between mercury content and moult. Mar Pollut Bull 17:27-30

García-Fernández AJ, Espín S, Martínez-López E (2013) Feathers as a biomonitoring tool of polyhalogenated compounds: a review. Environ Sci Technol 47:3028-3043

Groscolas R, Cherel Y (1992) How to molt while fasting in the cold: the metabolic and hormonal adaptations of emperor and king penguins. Ornis Scand 23:328-334

Hobson KA (2011) Isotopic ornithology: a perspective. J Ornithol 152(Suppl 1):S49-S66

Hobson KA, Clark RG (1992) Assessing avian diets using stable isotopes. I. Turnover of ${ }^{13} \mathrm{C}$ in tissues. Condor $94: 181-188$

Inger R, Bearhop S (2008) Applications of stable isotope analyses to avian ecology. Ibis 150:447-461

Jaeger A, Blanchard P, Richard P, Cherel Y (2009) Using carbon and nitrogen isotopic values of body feathers to infer inter-and intra-individual variations of seabird feeding ecology during moult. Mar Biol 156:12331240

Jaeger A, Cherel Y (2011) Isotopic investigation of contemporary and historic changes in penguin trophic niches and carrying capacity of the Southern Indian Ocean. PLoS ONE 6:e16484

Jaeger A, Connan M, Richard P, Cherel Y (2010) Use of stable isotopes to quantify seasonal changes of trophic niche and levels of population and individual specialisation in seabirds. Mar Ecol Progr Ser 401:269-277

Nakagawa S, Schielzeth H (2010) Repeatability for Gaussian and non-Gaussian data: a practical guide for biologists. Biol Rev 85:935-956

Ofukany AFA, Hobson KA, Wassenaar LI (2012) Connecting breeding and wintering habitats of migratory piscivorous birds: implications for tracking contaminants ( $\mathrm{Hg})$ using multiple stable isotopes. Environ Sci Technol 46:3263-3272

Phillips RA, Hamer KC (2000) Postnatal development of northern fulmar chicks, Fulmarus glacialis. Physiol Biochem Zool 73:597-604

R Core Team (2012) R: a language and environment for statistical computing. R Foundation for Statistical Computing, Vienna, Austria

Ramos R, Ramirez F, Jover L (2013) Trophodynamics of inorganic pollutants in a wide-range feeder: the relevance of dietary inputs and biomagnification in the yellow-legged gull (Larus michahellis). Environ Pollut 172:235-242 
Sears J, Hatch SA, O’Brien DM (2009) Disentangling effects of growth and nutritional status on seabird stable isotope ratios. Oecologia 159:41-48

Stettenheim PR (2000) The integumentary morphology of modern birds — an overview. Am Zool 40:461-477

Stewart FM, Phillips RA, Catry P, Furness RW (1997) Influence of species, age and diet on mercury concentrations in Shetland seabirds. Mar Ecol Prog Ser 151:237-244

Thompson DR, Furness RW, Lewis SA (1993) Temporal and spatial variation in mercury concentrations in some albatrosses and petrels from the sub-Antarctic. Polar Biol 13:239-244

Vo A-TE, Bank MS, Shine JP, Edwards SV (2011) Temporal increase in organic mercury in an endangered pelagic seabird assessed by century-old museum specimens. Proc Nat Acad Sci USA 108:7466-7471 
Table 1 Feather $\delta^{13} \mathrm{C}$ and $\delta^{15} \mathrm{~N}$ values and $\mathrm{Hg}$ concentrations in white-chinned petrel chicks,

Antarctic prion adults and king penguin adults. Abbreviations: CV, coefficient of variation; Id: individual. Values are means \pm SD of four feathers per individual bird

\begin{tabular}{|c|c|c|c|c|c|c|c|c|c|c|}
\hline \multirow[b]{2}{*}{ Id } & \multicolumn{3}{|c|}{$\delta^{13} \mathrm{C}(\%)$} & \multicolumn{3}{|c|}{$\delta^{15} \mathrm{~N}(\%)$} & \multicolumn{4}{|c|}{$\mathrm{Hg}\left(\mu \mathrm{gg}^{-1} \mathrm{dw}\right)$} \\
\hline & Min & $\operatorname{Max}$ & Mean \pm SD & Min & Max & Mean \pm SD & Min & $\operatorname{Max}$ & Mean \pm SD & $\mathrm{CV}(\%)$ \\
\hline \multicolumn{11}{|c|}{ White-chinned petrel chicks } \\
\hline 1 & -21.7 & -21.0 & $-21.3 \pm 0.3$ & 11.4 & 12.2 & $11.9 \pm 0.3$ & 1.22 & 1.51 & $1.35 \pm 0.12$ & 8.86 \\
\hline 2 & -20.7 & -20.6 & $-20.6 \pm 0.1$ & 12.5 & 12.9 & $12.7 \pm 0.2$ & 2.06 & 2.20 & $2.11 \pm 0.06$ & 2.95 \\
\hline 3 & -23.0 & -22.7 & $-22.8 \pm 0.1$ & 10.8 & 11.1 & $11.0 \pm 0.1$ & 1.01 & 1.22 & $1.09 \pm 0.09$ & 8.35 \\
\hline 4 & -20.6 & -20.5 & $-20.6 \pm 0.1$ & 12.5 & 13.2 & $12.8 \pm 0.3$ & 1.93 & 2.33 & $2.18 \pm 0.17$ & 7.91 \\
\hline 5 & -22.3 & -21.8 & $-22.0 \pm 0.2$ & 11.7 & 11.9 & $11.8 \pm 0.1$ & 2.47 & 2.93 & $2.72 \pm 0.19$ & 6.99 \\
\hline 6 & -21.5 & -21.0 & $-21.2 \pm 0.2$ & 12.0 & 12.3 & $12.2 \pm 0.1$ & 1.47 & 1.74 & $1.59 \pm 0.12$ & 7.70 \\
\hline 7 & -20.3 & -20.1 & $-20.2 \pm 0.1$ & 12.7 & 13.1 & $12.9 \pm 0.2$ & 2.85 & 3.42 & $3.11 \pm 0.25$ & 8.12 \\
\hline 8 & -21.6 & -21.4 & $-21.5 \pm 0.1$ & 12.2 & 12.3 & $12.2 \pm 0.1$ & 1.61 & 1.81 & $1.74 \pm 0.09$ & 5.08 \\
\hline 9 & -22.1 & -22.0 & $-22.1 \pm 0.1$ & 11.3 & 11.4 & $11.4 \pm 0.1$ & 1.28 & 1.40 & $1.34 \pm 0.06$ & 4.13 \\
\hline 10 & -21.1 & -20.7 & $-20.9 \pm 0.2$ & 12.7 & 13.0 & $12.8 \pm 0.1$ & 2.40 & 2.73 & $2.59 \pm 0.14$ & 5.32 \\
\hline \multicolumn{11}{|c|}{ Antarctic prion adults } \\
\hline 1 & -18.7 & -18.4 & $-18.6 \pm 0.2$ & 8.8 & 9.4 & $9.1 \pm 0.2$ & 1.73 & 3.79 & $2.87 \pm 1.07$ & 37.3 \\
\hline 2 & -18.4 & -16.9 & $-18.0 \pm 0.7$ & 9.7 & 15.2 & $11.7 \pm 2.4$ & 1.35 & 2.89 & $2.39 \pm 0.71$ & 29.7 \\
\hline 3 & -21.6 & -16.7 & $-18.6 \pm 2.1$ & 9.0 & 13.0 & $10.9 \pm 1.7$ & 1.13 & 3.45 & $2.40 \pm 0.96$ & 39.9 \\
\hline 4 & -19.0 & -17.9 & $-18.4 \pm 0.5$ & 8.5 & 10.8 & $9.2 \pm 1.1$ & 1.14 & 2.86 & $1.86 \pm 0.78$ & 42.0 \\
\hline 5 & -19.1 & -18.6 & $-18.8 \pm 0.2$ & 8.2 & 9.4 & $8.6 \pm 0.6$ & 1.00 & 1.77 & $1.35 \pm 0.40$ & 29.8 \\
\hline 6 & -21.3 & -18.3 & $-19.4 \pm 1.3$ & 8.3 & 9.9 & $9.3 \pm 0.7$ & 1.68 & 2.42 & $2.13 \pm 0.36$ & 15.3 \\
\hline 7 & -18.6 & -16.4 & $-17.9 \pm 1.0$ & 8.4 & 14.0 & $10.0 \pm 2.7$ & 1.53 & 3.11 & $2.26 \pm 0.84$ & 37.3 \\
\hline 8 & -18.3 & -17.8 & $-18.0 \pm 0.2$ & 9.1 & 10.1 & $9.7 \pm 0.4$ & 0.97 & 1.59 & $1.30 \pm 0.25$ & 19.6 \\
\hline 9 & -18.7 & -16.3 & $-17.4 \pm 1.2$ & 9.1 & 11.3 & $10.4 \pm 1.0$ & 1.47 & 4.89 & $2.70 \pm 1.61$ & 59.8 \\
\hline 10 & -19.3 & -17.8 & $-18.5 \pm 0.6$ & 8.6 & 10.8 & $9.4 \pm 1.0$ & 2.40 & 4.77 & $3.95 \pm 1.08$ & 27.3 \\
\hline \multicolumn{11}{|c|}{ King penguin adults } \\
\hline 1 & -21.4 & -21.0 & $-21.2 \pm 0.2$ & 10.7 & 11.1 & $11.0 \pm 0.1$ & 2.18 & 2.36 & $2.27 \pm 0.08$ & 3.52 \\
\hline 2 & -20.1 & -19.8 & $-19.9 \pm 0.1$ & 11.3 & 11.7 & $11.5 \pm 0.2$ & 3.78 & 3.82 & $3.80 \pm 0.02$ & 0.54 \\
\hline 3 & -21.2 & -21.0 & $-21.1 \pm 0.1$ & 11.3 & 11.5 & $11.4 \pm 0.1$ & 2.07 & 2.36 & $2.22 \pm 0.14$ & 6.38 \\
\hline 4 & -21.5 & -21.2 & $-21.4 \pm 0.1$ & 10.7 & 11.1 & $10.8 \pm 0.2$ & 2.78 & 2.97 & $2.88 \pm 0.08$ & 2.79 \\
\hline 5 & -20.6 & -20.3 & $-20.5 \pm 0.1$ & 11.0 & 11.1 & $11.1 \pm 0.1$ & 2.48 & 2.74 & $2.57 \pm 0.12$ & 4.69 \\
\hline 6 & -20.0 & -19.8 & $-19.9 \pm 0.1$ & 12.1 & 12.3 & $12.2 \pm 0.1$ & 3.15 & 3.77 & $3.41 \pm 0.28$ & 8.20 \\
\hline 7 & -22.9 & -22.1 & $-22.3 \pm 0.4$ & 11.1 & 11.6 & $11.4 \pm 0.2$ & 2.33 & 2.41 & $2.37 \pm 0.04$ & 1.84 \\
\hline
\end{tabular}


Table 2 Variance parameters and intra-class correlation coefficients (ICC) of linear mixed effects models with the individual as a random intercept (random effects models) for whitechinned petrel chicks, Antarctic prion adults and king penguin adults. Abbreviations: d, variance explained by the model, here the between-individual variance; $\sigma$, residual variance

\begin{tabular}{|c|c|c|c|c|c|c|c|c|c|}
\hline \multirow[b]{2}{*}{ Species } & \multicolumn{3}{|c|}{$\delta^{13} \mathrm{C}$} & \multicolumn{3}{|c|}{$\delta^{15} \mathrm{~N}$} & \multicolumn{3}{|c|}{$\mathrm{Hg}$} \\
\hline & $d^{2}$ & $\sigma^{2}$ & ICC & $d^{2}$ & $\sigma^{2}$ & ICC & $d^{2}$ & $\sigma^{2}$ & ICC \\
\hline White-chinned petrel chicks $(n=10)$ & 0.64 & 0.03 & 0.96 & 0.44 & 0.04 & 0.92 & 0.45 & 0.02 & 0.96 \\
\hline Antarctic prion adults $(\mathrm{n}=10)$ & 0.07 & 0.99 & 0.07 & 0.40 & 1.99 & 0.17 & 0.40 & 0.81 & 0.33 \\
\hline King penguin adults $(\mathrm{n}=7)$ & 0.72 & 0.03 & 0.96 & 0.21 & 0.02 & 0.91 & 0.37 & 0.02 & 0.95 \\
\hline
\end{tabular}




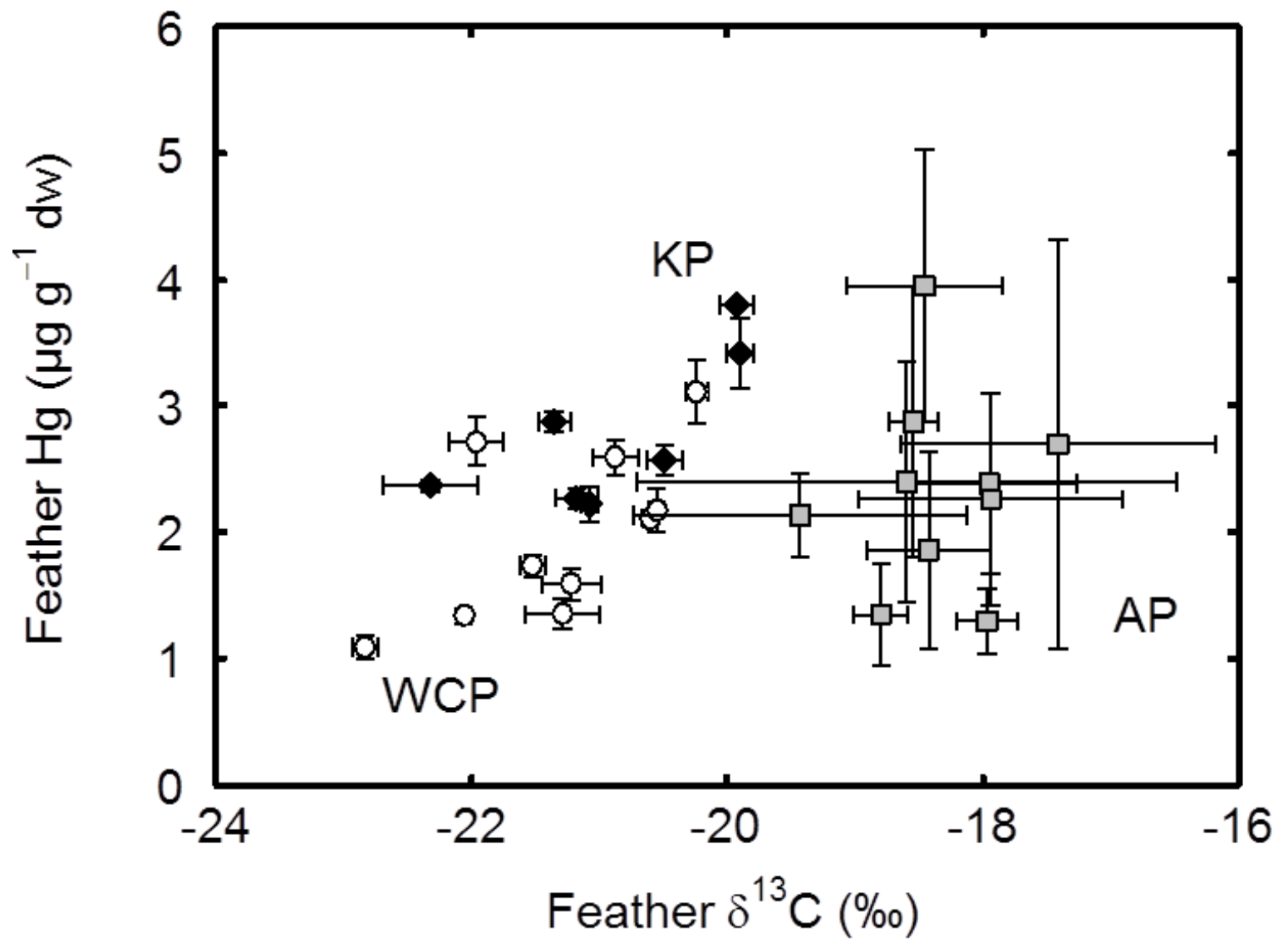

Figure 1. Simultaneously-moulting white-chinned petrel chicks (WCP; white circles) and king penguin adults (KP; black diamonds) show smaller SD in both feather $\delta 13 \mathrm{C}$ and $\mathrm{Hg}$ values than sequentially-moulting Antarctic prion adults (AP; grey squares). Values are means \pm SD of four feathers per individual bird. 